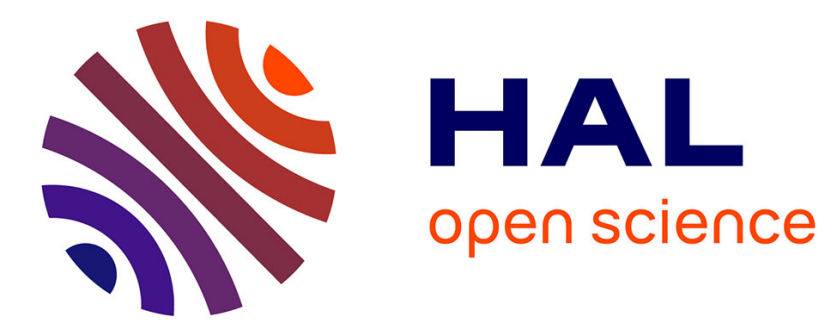

\title{
A 7-Level Single DC Source Cascaded H-Bridge Multilevel Inverters Control Using Hybrid Modulation
}

Farid Khoucha, Achour Ales, Abdelkader Khoudiri, Khoudir Marouani, Mohamed Benbouzid, Abdelaziz Kheloui

\section{- To cite this version:}

Farid Khoucha, Achour Ales, Abdelkader Khoudiri, Khoudir Marouani, Mohamed Benbouzid, et al.. A 7-Level Single DC Source Cascaded H-Bridge Multilevel Inverters Control Using Hybrid Modulation. ICEM'10, Sep 2010, Rome, Italy. 5pp. hal-00532661

\section{HAL Id: hal-00532661 https://hal.science/hal-00532661}

Submitted on 4 Nov 2010

HAL is a multi-disciplinary open access archive for the deposit and dissemination of scientific research documents, whether they are published or not. The documents may come from teaching and research institutions in France or abroad, or from public or private research centers.
L'archive ouverte pluridisciplinaire HAL, est destinée au dépôt et à la diffusion de documents scientifiques de niveau recherche, publiés ou non, émanant des établissements d'enseignement et de recherche français ou étrangers, des laboratoires publics ou privés. 


\title{
A 7-Level Single DC Source Cascaded H-Bridge Multilevel Inverters Control Using Hybrid Modulation
}

\author{
F. Khoucha, A. Ales, A. Khoudiri, K. Marouani, M.E.H. Benbouzid and A. Kheloui
}

\begin{abstract}
This paper presents a new hybrid cascaded Hbridge multilevel inverter (HCMLI) motor drive DTC control scheme for electric vehicles or hybrid electric vehicles where each phase of the inverter can be implemented using only a single DC source. Traditionally, each phase of the inverter require $n$ DC source for $2 n+1$ output voltage levels. In this paper, a scheme is proposed that allows the use of a single DC source as the first DC source which would be available from batteries or fuel cells, with the remaining $(n-1)$ DC sources being capacitors. This scheme can simultaneously maintain the DC voltage level of the capacitors, produce a nearly sinusoidal output voltage due to its high number of output levels and therefore a high performance and also efficient torque and flux controller is obtained, enabling a DTC solution for hybrid multilevel inverter powered motor drives.
\end{abstract}

Index Terms-Cascaded multilevel inverter, hybrid modulation, DTC.

\section{INTRODUCTION}

$\mathrm{T}$ HE electric vehicles (EV) and Hybrid Electric Vehicles (HEV) currently seem to constitute an increasingly effective alternative to the conventional vehicles, allowing to the vehicle manufacturers to be able to fulfill the requirements required by the users of vehicles (dynamic performances and fuel consumption) and the environmental constraints (reduction of the pollutant emissions). The electric propulsion system is the heart of EV [1]. It consists of the motor drive, transmission device, and wheels. In fact, the motor drive, comprising the electric motor, the power converter, and the electronic controller, is the core of the EV propulsion system. The motor drive is configured to respond to a torque demand set by the driver.

The induction motor seems to be a very interesting solution for EV's propulsion. Field Oriented Control (FOC) [2] and Direct Torque Control (DTC) [3-4] have emerged as the standard industrial solutions to achieve high dynamic performance. However some drawbacks of both methods have motivated important research efforts in the last decades. Particularly for DTC, the high torque ripple and the variable switching frequency introduced by the hysteresis comparators have been extensively addressed [5-6]. In addition, several contributions that combine DTC principles together with PWM and SVM have been reported to correct these problems. This approach is based on the load angle

F. Khoucha and M.E.H. Benbouzid are with the University of Brest, EA 4325 LBMS, Rue de Kergoat, CS 93837, 29238 Brest Cedex 03, France (e-mail: Mohamed.Benbouzid@univ-brest.fr). F. Khoucha is also with the Electrical Engineering Department, Polytechnic Military Academy, 16111 Algiers, Algeria.

A. Ales, A, Khoudiri, K. Marouani and A. Kheloui are with the Electrical Engineering Department, Polytechnic Military Academy, 16111 Algiers, Algeria. control, from which a voltage reference vector is computed which is finally modulated by the inverter [7]. Although one major feature of classic DTC is the absence of modulators and linear controllers, this approach has shown significant improvements and achieves similar dynamic performance.

On the other hand, the power converter technology is continuously developing, and cascaded multilevel inverters have become a very attractive solution for EV applications, due to its modular structure, higher voltage capability, reduced common mode voltages, near sinusoidal outputs, and smaller or even no output filter [8]. In general, cascaded multilevel inverter may be classified in two groups. The first one refers to the amplitude of isolated DC sources devoted to supply each H-bridge cell. If the amplitude of all sources is equal, then the inverter is called symmetrical, otherwise, if at least one of the sources present different amplitude, then it will be called asymmetrical. The second classification label the multilevel inverter whether hybrid or not. If the converter is implemented with different technologies of semiconductor devices (IGBTs, SCRs, GTOs, IGCTs), different nature of DC sources (fuel cells, batteries and supercapacitors) and/or if it presents a hybrid modulation strategy, then it is classified as hybrid [9-10]. This structure greatly simplifies the converter complexity.

The proposed control algorithm eliminates the need of additional isolated DC sources. The control strategy regulates the DC link voltages of capacitors connected to the smallest voltages of a two cells 7-level cascaded H-bridge inverter. The obtained results validate the voltage control strategy and confirm the high dynamic performance of the proposed method, presenting very low torque ripple

\section{MultileVel INVERTER TOPOLOGy}

The power circuit of the Cascaded H-Bridge Multilevel Inverter is illustrated in Fig. 1. The inverter is composed by the series connection of power cells, each one containing an $\mathrm{H}$-bridge inverter and an isolated dc-source. In the particular case of asymmetric inverters these sources are not equal ( $V_{1}$ $>V_{2}$ ). The asymmetry of the input voltages can reduce, or when properly designed, eliminate redundant output levels, maximizing the number of different levels generated by the inverter.

Therefore this topology can achieve the same output voltage quality with less number of semiconductors, space, costs and internal fault probability than the symmetric fed topology.

A particular cell $i$ can generate three voltage levels $\left(+V_{i}\right.$, $\left.0,-V_{i}\right)$. The total inverter output voltage for a particular phase $j$ is then defined by

$v_{i N}=\sum_{j=1}^{m} v_{i j}=\sum_{j=1}^{m} V_{j}\left(S_{j 1}-S_{j 2}\right), \quad i \in\{a, b, c\}$ 


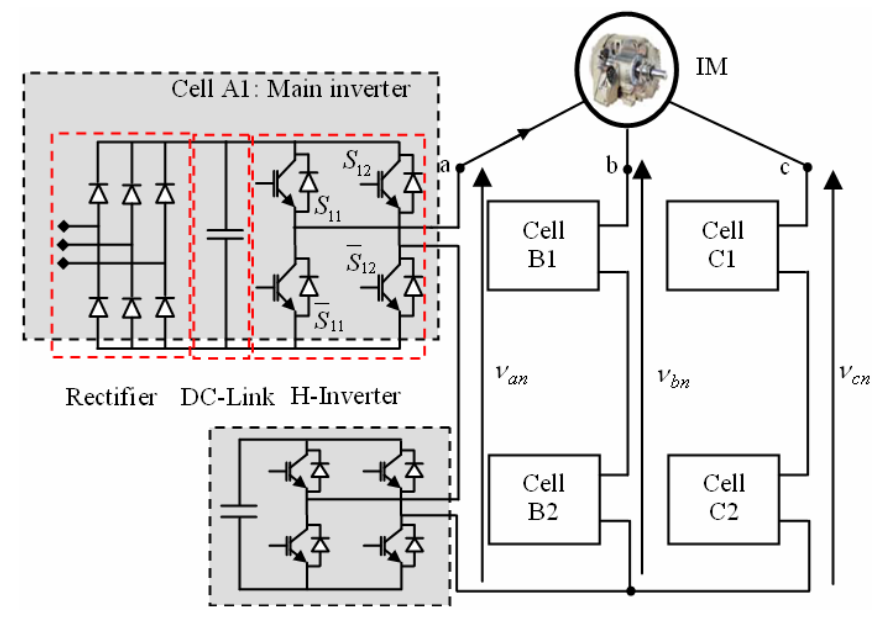

Fig.1. Hybrid cascaded multilevel converter topology.

Where $v_{i N}$ is the total output voltage of phase $i$ (respectively, the neutral of the inverter $N$ ), is the output voltage of cell of phase, and the switching state associated to cell. Note how the output voltage of one cell is defined by one of the four binary combinations of the switching state, with " 1 " and " 0 " representing the "On" and "Off" states of the corresponding switch, respectively.

The inverter generates different voltage levels (e.g. an inverter with $m=4$ cells can generate $\left(2^{m+1}-1=31\right)$ different voltage levels). When using three-phase systems, the number of different voltage vectors is given by $3 n_{1}\left(n_{1}-\right.$ $1)+1$, where $n_{1}$ is the number of levels. For example, for the $m=4$ case with 31 levels there are 2791 different voltage vectors. Table I summarizes the output levels for an asymmetric 7-level inverter using only $\mathrm{m}=2$ cells per phase (only phase is given). An example of the voltage waveform generation for an asymmetric seven-level inverter is illustrated in Fig. 2.

TABLE I

7-LEVEL ASYMMETRIC CASCADED INVERTER SWITCHING STATES.

\begin{tabular}{ccccccccc}
\hline$n_{1}$ & \multicolumn{3}{c}{ Cell 1} & \multicolumn{3}{c}{ Cell 2 } & Total \\
\cline { 2 - 8 } & $S_{11}$ & $S_{11}$ & $v_{a 1}$ & $S_{21}$ & $S_{22}$ & $v_{a 2}$ & $v_{a N}$ \\
1 & 1 & 0 & $3 v_{d c}$ & 0 & 0 & 0 & $3 v_{d c}$ \\
2 & 1 & 0 & $3 v_{d c}$ & 0 & 1 & $-v_{d c}$ & $2 v_{d c}$ \\
3 & 0 & 0 & 0 & 1 & 0 & $v_{d c}$ & $v_{d c}$ \\
4 & 0 & 0 & 0 & 0 & 0 & 0 & 0 \\
5 & 0 & 0 & 0 & 0 & 1 & $-v_{d c}$ & $-v_{d c}$ \\
6 & 0 & 1 & $-3 v_{d c}$ & 1 & 0 & $v_{d c}$ & $-2 v_{d c}$ \\
\hline 7 & 0 & 1 & $-3 v_{d c}$ & 0 & 0 & 0 & $-3 v_{d c}$ \\
\hline
\end{tabular}
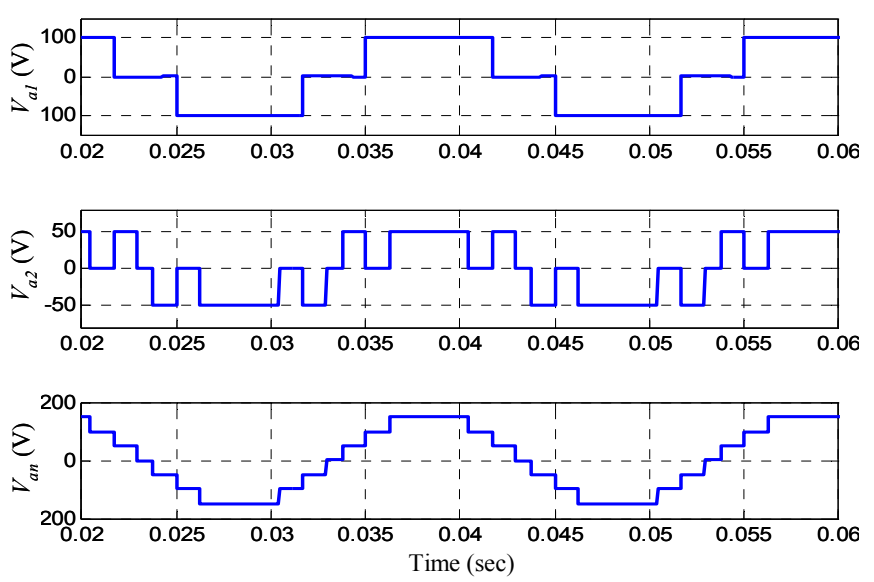

Fig. 2. Asymmetric multilevel inverter with 7-levels output voltage synthesis.

\section{DTC-PWM CONTROL}

\section{A. DTC Basic Principles}

The stator voltage space vector $\left(\boldsymbol{v}_{s}\right)$ of an $\mathrm{AC}$ motor is related to the stator flux vector $\psi_{s}$ in a stator fixed coordinate system by

$v_{s}=R_{s} i_{s}+\frac{d \psi_{s}}{d t}$

Neglecting the voltage drop in the stator resistance $R_{s}$, the stator flux vector is the time integral of the stator voltage vector. Hence, for a small sampling period $T_{s}$, (2) can be expressed by

$\Delta \psi_{s} \approx v_{s} T_{s}$

On the other hand, the motor torque $\left(T_{e}\right)$ is related to the stator and rotor fluxes by

$T_{e}=\frac{3}{2} p \frac{k}{\sigma L_{s}}\left|\psi_{s}\right|\left|\psi_{r}\right| \sin (\delta)$

where $\delta$, known as load angle, is the angle between stator and rotor fluxes, $p$ is the pole pairs number, $k=L_{m} / L_{s}$, and the leakage factor $\sigma=1-L_{m}{ }^{2} / L_{s} L_{r}$, with $L_{s}, L_{r}$ and $L_{m}$ are the stator, the rotor and the mutual inductances respectively. If both flux magnitudes are kept constant in (4), the torque can be controlled directly by changing the load angle. This can be easily achieved, since variations in the stator flux vector change the load angle due to slower rotor flux dynamics. Considering (3) and (4) it follows that the stator voltage vector can be used to manipulate the load angle, and consequently to control the torque.

\section{B. Flux and Torque Control by Load Angle Tracking}

In traditional DTC, the influence over the load angle of each voltage vector generated by the inverter is determined and stored in a lookup table, according to the stator flux position in the complex plane. This is difficult to extend for multilevel inverter fed drives, where the complexity increases in huge proportions in relation to the levels generated by the inverter. Therefore it is easier to look at the problem in a different way: the torque error can be used to generate a reference load angle $\delta^{*}$ necessary to correct the torque behavior. Then the desired load angle can be used to compute the exact voltage vector that will produce the necessary flux variation $\Delta \psi_{s}$. This principle is illustrated in Fig. 3. Note that once provided the reference load angle $\delta^{*}$, the reference stator flux vector $\psi_{s}{ }^{*}$ can be computed by

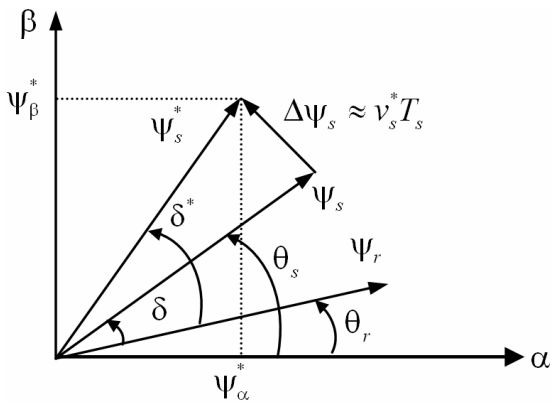

Fig. 3. Stator voltage vector influence over the stator flux vector. 


$$
\psi_{s}^{*}=\left|\psi_{s}^{*}\right| \cos \left(\delta^{*}+\theta_{r}\right)+j\left|\psi_{s}^{*}\right| \sin \left(\delta^{*}+\theta_{r}\right)
$$

where $\left|\psi_{s}{ }^{*}\right|$ is the fixed stator flux amplitude reference, and $\theta_{r}$ is the rotor flux vector angle. Note that $\left(\delta^{*}+\theta_{r}\right)$ corresponds to the reference stator flux vector angle $\theta_{s}{ }^{*}$. by

Then the desired stator voltage vector $v_{s}^{*}$ can be obtained

$$
v_{s} \approx \frac{\Delta \psi_{s}}{T_{s}}=\frac{\psi_{s}^{*}-\psi_{s}}{T_{s}}
$$

Finally $v_{s}^{*}$ has to be generated by the inverter. This is commonly performed with PWM or SVM for 2-level inverters [11]. The use of a multilevel inverter will reduce the torque ripple amplitude due to the reduction of the rate of change of the common-mode voltage (number of step variations in a fixed time span), and in this case using the hybrid modulation method [12], a fixed-frequency output voltage will be obtained concentrating the voltage spectrum around the carrier frequency of the small power cell. Hence the most important drawbacks of traditional DTC are corrected. A simplified control diagram of the proposed strategy is shown in Fig. 4. The outer speed control loop is omitted.

\section{HYBRID MODULATION STRATEGY}

The hybrid modulation is specially conceived for the asymmetric multilevel H-bridge inverter structure [13]. The basic idea is to take advantage of the different power rates among the cells to reduce switching losses and improve the converter efficiency. From Fig. 5 it can be seen that the inverter generates a rectangular waveform, which is at the same frequency of the reference (turn-on and -off only one time during a half reference cycle). The remaining of the output voltage, second trace in Fig. 5, is synthesized by the auxiliary inverter at high switching frequency (with sinusoidal PWM). This completes the generation of a multilevel stepped waveform with a high frequency component (similar to a multicarrier based PWM), but with the difference that fewer switching losses are produced to achieve it. Typical output waveform of the inverter using this modulation is shown in the third trace of Fig. 5. Note that the output has 7 different voltage levels given by all the possible combinations of the series connection of $\left(+V_{d c}\right.$, $\left.0,-V_{d c}\right)$ and $\left(+2 V_{d c}, 0,-2 V_{d c}\right)$.

\section{CAPACITOR VOLTAGE CONTROL}

Capacitor voltage control in the auxiliary inverter is a challenging task [14-15]. In the proposed method, it is based on the hybrid modulation that consists of adjusting the turnon of the main inverter, which is revealed by adjusting the active and reactive power that the main inverter injects to the load (if $\alpha$ is chosen to be exactly $18^{\circ}$, the main inverter injects only active power). By shifting the voltage waveform synthesized by the main inverter (Fig. 6), one could also inject some reactive power, which can be used to charge or discharge the capacitor on the auxiliary inverter.

Therefore, the proposed algorithm (Fig. 7) regulates the capacitor voltage by an appropriate adjustment of $\Delta \alpha$ which is given by the PI regulator and acts directly on the variation of the comparison level $V_{c m}$ that controls the main inverter turn-on and -of. The closed loop regulation for each phase is done by measuring the capacitor voltage.
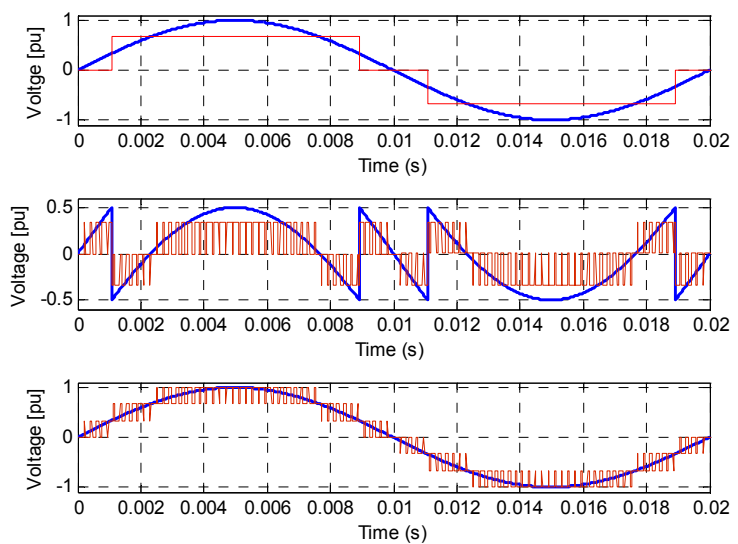

Fig. 5. Desired output, auxiliary and main inverter voltage waveforms.

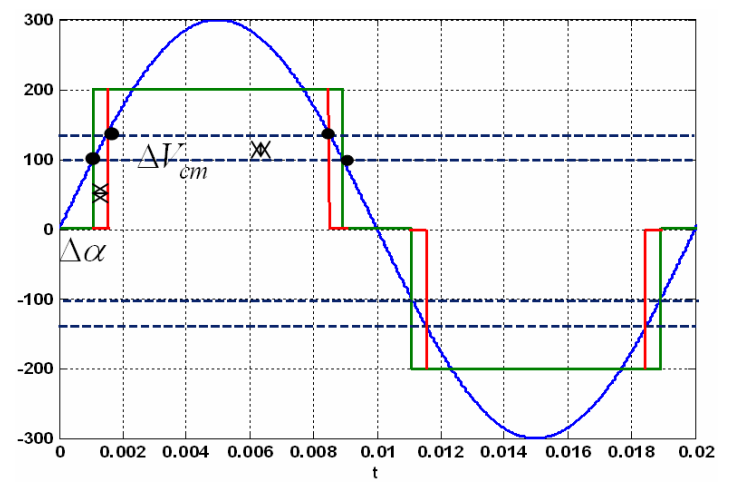

Fig. 6. Variation of the main inverter conduction angle by $V_{c m}$ variation.

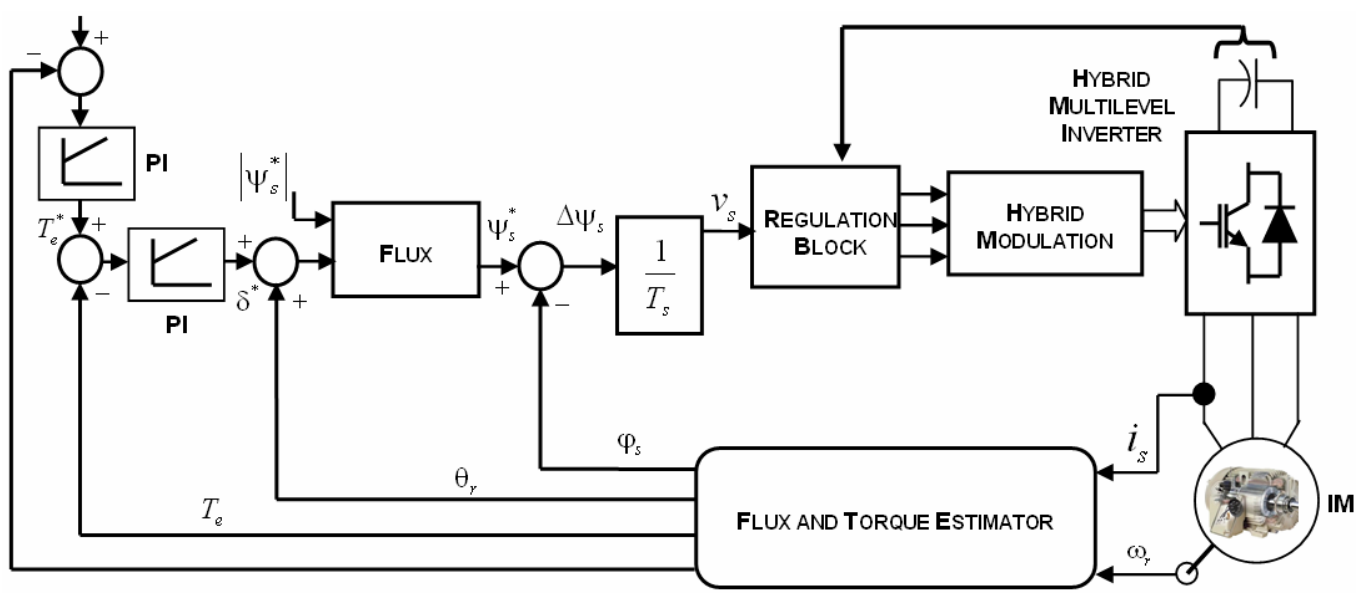

Fig. 4. Hybrid multilevel inverter-fed DTC motor drive with the single DC source. 


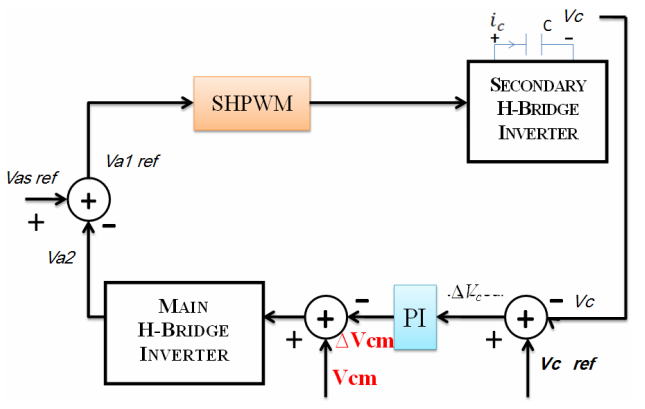

Fig. 7. Closed-loop control of the capacitor voltages.

From the capacitors voltage error, the PI regulator gives directly the necessary $\Delta V_{c m}$ to be added to the initial comparison level which leads to change the conduction angle $(\alpha)$ of the main inverter that allows the secondary inverter capacitor charging.

\section{SimUlations RESUltS AND Discussions}

To evaluate the dynamic performances of the proposed control strategy, numerical simulations have been carried-out on an EV propelled by an induction motor supplied with 7-level single DC source cascaded multilevel inverter. These were done using the standardized ECE-15 and EUDC driving cycle. The achieved performances are illustrated by Figs. 8 to 13 .

The simulation results show that the speed reference required by the driver is well-tracked as shown by Fig. 8 . One can see that the induction motor developed torque presents fewer ripples compared to a traditional DTC (Fig. 9.). This is due to the quality of the voltage supplying the inverter (Fig. 13.). Consequently, the stator currents are almost sinusoidal (Fig. 10) and a better dynamics is obtained; operating practically with constant flux (Fig. 11).

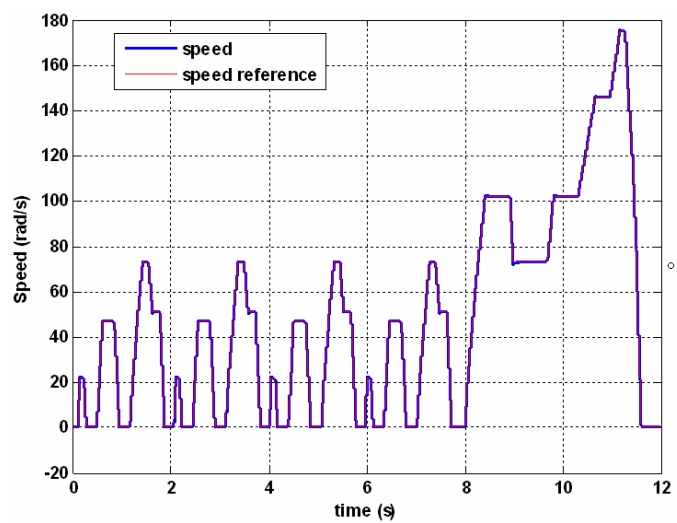

Fig. 8. Speed with the ECE-15 + EUDC driving cycle.

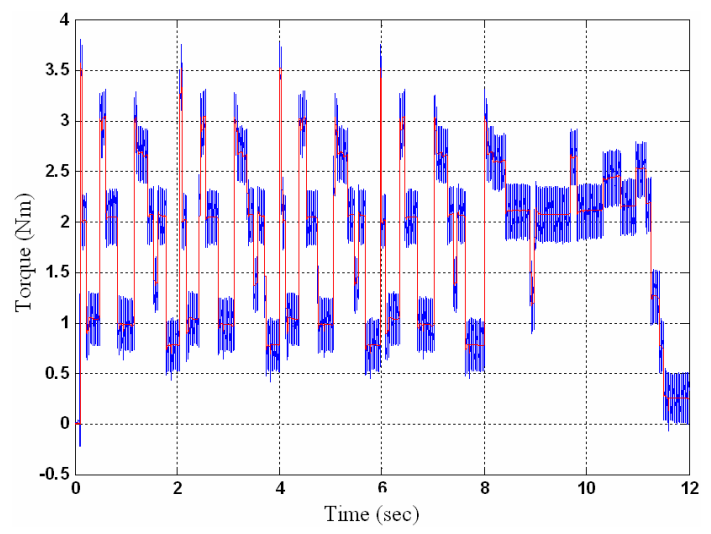

Fig .9. Reference and developed torques.

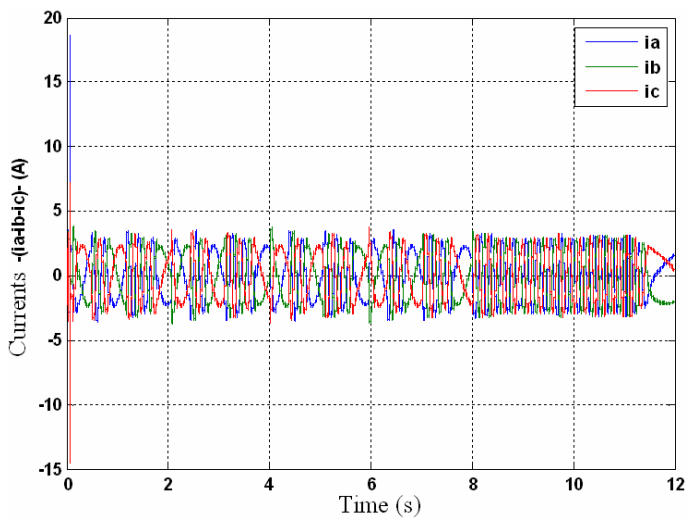

Fig. 10. Stator currents waveforms.
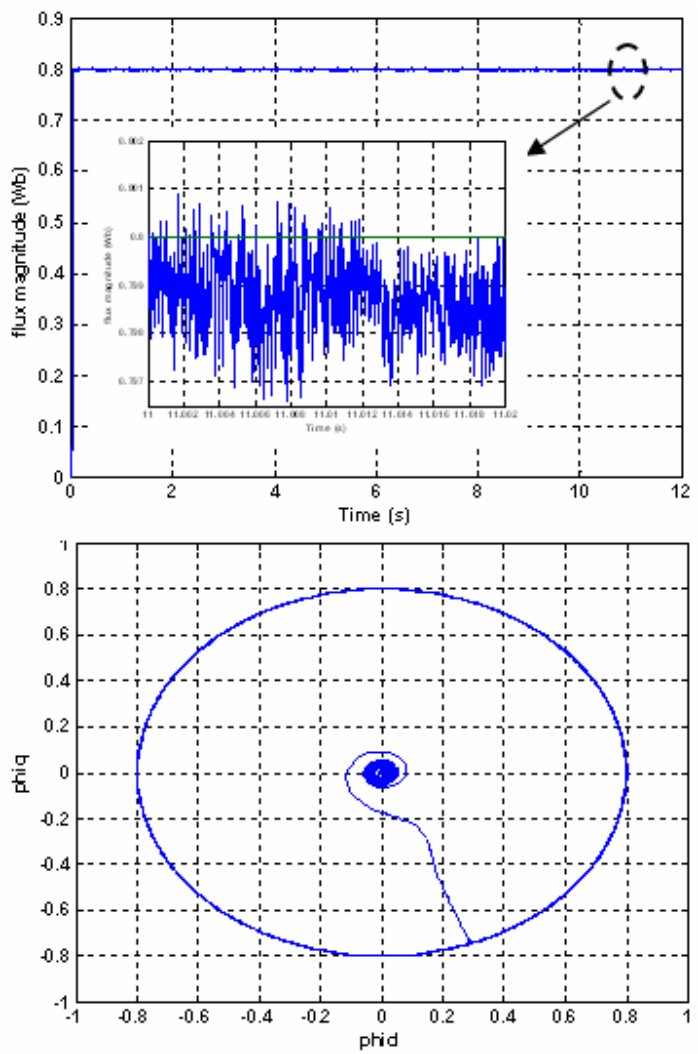

Fig. 11. Magnitude and locus of the stator flux in the DTC-PWM.

Figure 12 shows the capacitor voltages waveforms which supply each auxiliary H-bridge of the three phase hybrid multilevel inverter. One can notice they oscillate around their reference values and they are quiet identical. However, their difference become very large when there is a significant acceleration or deceleration requested by the driver. Indeed, in these cases, different amounts of energy are required due to fast variation of the induction motor operating point.

Simulation results confirm that independently of the value the requested speed and torque, the capacitor voltages are controlled and the validity of the proposed control method is proven.

\section{CONCLUSION}

In this paper a control strategy has been proposed for a hybrid cascaded multilevel inverter with a modified DTC scheme used for induction motor-based EV propulsion. In this case, the main inverter uses a single DC voltage source and the auxiliary inverter capacitor voltages are controlled in each phase. 

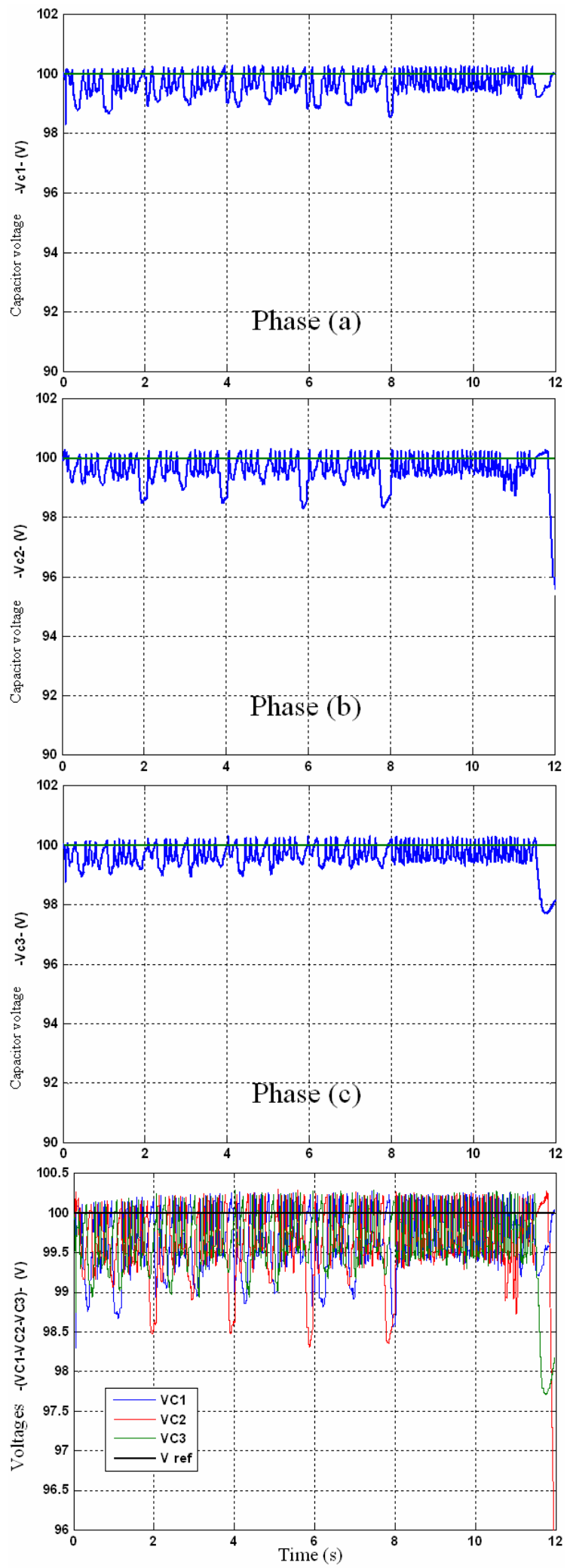

Fig. 12. Capacitor voltage waveforms.

In addition, the DTC-PWM allows the operation with a fixed switching frequency, the reduction in the torque ripple without output filter, and high performance torque and flux control.

The proposed control method simplifies the DTC application in embedded systems by reducing the inverter cost and complexity by decreasing the semi-conductor and the source numbers. Moreover, there is no need for hysteresis comparators, and lookup tables which make this control method very attractive in such applications.

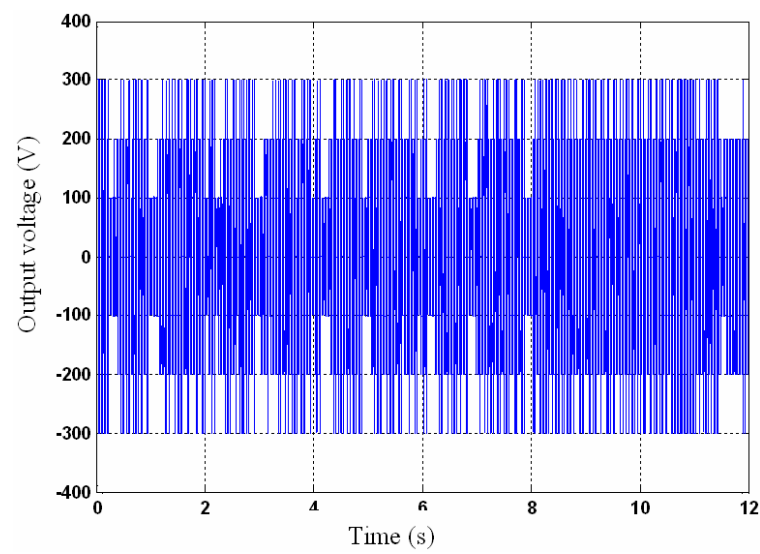

Fig.13. Output voltage waveform.

\section{REFERENCES}

[1] M.E.H. Benbouzid et al., "Electric motor drive selection issues for HEV propulsion systems: A comparative study," IEEE Trans. Vehicular Technology, vol. 55, nº, pp. 1756-1764, November 2006.

[2] D.O. Neacsu et al., "Comparative analysis of torque-controlled IM drives with applications in electric and hybrid vehicles vehicle," IEEE Trans. Power Electronics, vol. 16, n², pp. 240-247, March 2001.

[3] A. Haddoun et al., "A loss-minimization DTC scheme for EV induction motors," IEEE Trans. Vehicular Technology, vol. 56, $\mathrm{n}^{\circ} 1$, pp. 81-88, January 2007.

[4] D. Casadei et al., "Performance analysis of a speed-sensorless induction motor drive based on a constant switching-frequency DTC scheme," IEEE Trans. Industry Applications, vol. 39, no. 2, pp. 476484, March-April 2003.

[5] C.A. Martins et al., "Switching frequency imposition and ripple reduction in DTC drives by using a multilevel converter," IEEE Trans. Power Electronics, vol. 17, no. 2, pp.286-297, March 2002.

[6] J. Rodriguez et al., "Direct torque control with imposed switching frequency in an 11-level cascaded inverter," IEEE Trans. Industrial Electronics, vol. 51, n4, pp. 827-833, August 2008.

[7] G.S. Buja et al., "Direct torque control of PWM inverter-fed ac motors-A survey," IEEE Trans. Industrial Electronics, vol. 51, $\mathrm{n}^{\circ} 4$, pp 744-757, August 2004.

[8] J. Rodriguez et al., "Multilevel inverters: A survey of topologies, controls and applications," IEEE Trans. Industrial Electronics, vol. 49, $\mathrm{n}^{\circ} 4$, pp. 724-738, August 2002.

[9] F. Khoucha et al., "Hybrid cascaded H-bridge multilevel inverter motor drive DTC control for Electric Vehicles," in Proceedings of the ICEM'08, Vilamoura (Portugal), pp. 1-6, September 2008.

[10] C. Rech et al., "Impact of hybrid multilevel modulation strategies on input and output harmonic performance," IEEE Trans. Power Electronics, vol. 22, n³, pp. 967-977, May 2007.

[11] D. Casadei et al., "Two viable schemes for induction motors torque control," IEEE Trans. Power Electronics, vol. 17, n5, pp. 779-787, September 2002.

[12] M. Veenstra et al., "Control of a hybrid asymmetric multilevel inverter for competitive medium-voltage industrial drives," IEEE Trans. Industry Applications, vol. 41, n², pp. 655-664, March-April 2005.

[13] Z. Du et al., "A cascade multilevel inverter using a single fuel cell DC source," in Proceedings of the IEEE APEC'06, Dallas (USA), vol. 1, pp. 426-430, March 2006.

[14] K.A. Corzine et al., "A cascaded multilevel H-bridge inverter utilizing capacitor voltages sources," in Proceedings of the IASTED ICPES'03, Palm Springs (USA), pp. 290-295, February 2003.

[15] J. Liao et al., "Cascaded H-bridge multilevel inverters - A reexamination," in Proceedings of the IEEE VPPC'07, Arlington USA), pp. 203-207, September 2007. 